\title{
Kezdeti tapasztalataink spinalis muscularis atrophiában szenvedó gyermekek intravénás génterápiájával
}

\author{
Mikos Borbála dr. ${ }^{1}$ - Gergely Anita dr. ${ }^{1}$ - Balázsfi Réka dr. ${ }^{1}$ \\ Bányász Edina dr. ${ }^{1}$. Gyömörei Beáta dr. ${ }^{2}$. Hantos Mónika dr. ${ }^{3}$ \\ Czelecz Judit dr. ${ }^{2}$ - Jakus Rita dr. ${ }^{4}$ - Kárász Hajnalka dr. ${ }^{2}$ \\ Zilahy Mónika dr. ${ }^{5}$ - Molnár Eszter dr. ${ }^{6}$ - Paraicz Éva dr. ${ }^{7}$ \\ Csohány Ágnes dr. ${ }^{7}$. Szénási Fanni dr. ${ }^{5}$. Vendégh Lejla dr. ${ }^{5}$ \\ Fogarasi András dr. ${ }^{4}$ - Velkey György János dr. ${ }^{8}$
}

${ }^{1}$ A Magyarországi Református Egyház Bethesda Gyermekkórháza, Aneszteziológiai és Intenzív Terápiás Osztály, Budapest

${ }^{2}$ A Magyarországi Református Egyház Bethesda Gyermekkórháza, II. Csecsemő- és Gyermekgyógyászati Osztály, Budapest

${ }^{3}$ A Magyarországi Református Egyház Bethesda Gyermekkórháza, Intézeti Gyógyszertár, Budapest

${ }^{4}$ A Magyarországi Református Egyház Bethesda Gyermekkórháza, Gyermekneurológiai Osztály, Budapest ${ }^{5}$ A Magyarországi Református Egyház Bethesda Gyermekkórháza, III. Csecsemő- és Gyermekgyógyászati Osztály, Budapest

${ }^{6}$ A Magyarországi Református Egyház Bethesda Gyermekkórháza, Központi Laboratórium, Budapest ${ }^{7}$ A Magyarországi Református Egyház Bethesda Gyermekkórháza, Gyermekrehabilitációs Osztály, Budapest

${ }^{8}$ A Magyarországi Református Egyház Bethesda Gyermekkórháza, Budapest

A veleszületett gerincvelői izomsorvadás ritka, progresszív neurodegeneratív betegség, a gyermekkori halál egyik legjelentősebb genetikai oka. Az orvostudomány lehetőségei a XXI. század előtt a progresszió megfékezésére, a szövődmények késleltetésére és ellátására korlátozódtak. A legsúlyosabb génhibában szenvedő gyermekeket általában kétéves kor előtt elveszítettük. A genetikai diagnosztika fejlődése lehetővé teszi a korai diagnózist, a súlyosság és a progresszió elörejelzését. A 2018-ban hazánkban engedélyezett intrathecalis nuszinerszennel a nagy betegszámon alapuló klinikai eredmények meggyőzőek. A 2019-től elérhető új, intravénás génpótló terápiával (onaszemnogén abeparvovek) kapcsolatos tapasztalatok még kisebb betegszámon alapulnak. Hazánkban öt betegnél került sor az alkalmazására a Bethesda Gyermekkórházban, szigorú szakmai kritériumok és előkészületek alapján. Közülük annak a három gyermeknek a kezeléséról számolunk be dolgozatunkban, akiknél már rendelkezünk utánkövetési tapasztalatokkal. Vizsgálatunk szerint a készítmény elősegíti a mozgásteljesítmény javulását. A mellékhatások elsősorban reverzibilis májenzim-emelkedésben, thrombocytopeniában, granulocytopeniában és a szívizom-nekroenzim emelkedésében nyilvánultak meg. Ezért fontosnak tartjuk a betegek szoros és tartós követését, a mellékhatások korai észlelése és elhárítása érdekében.

Orv Hetil. 2020; 161(42): 1806-1816.

Kulcsszavak: adenoasszociált génterápia, mozgásteljesítmény, nuszinerszen, onaszemnogén abeparvovek, spinalis muscularis atrophia, Werdnig-Hoffmann-betegség

\section{Our initial experiences with intravenous gene therapy for spinal muscular atrophy in children}

Congenital spinal muscular atrophy is a rare, progressive neurodegenerative disease, one of the major genetic causes of childhood death. The possibilities of medicine to curb its progression and to delay and treat the disease's complications were limited before the 21 st century. Therefore, children with the most severe genetic defects were usually lost before their second birthday. Advances in genetic diagnostics allow for early diagnosis, prediction of severity and expected progression. Using intrathecal nusinersen (available in Hungary since 2018), clinical results based on a large number of patients are convincing. Experience with the new intravenous gene therapy (onasemnogene abeparvovec) 
available from 2019 is still based on a less number of patients. It was used in Hungary in Bethesda Hospital in five children based on strict professional criteria and preparations. Our paper summarizes the most important efficacy and safety data of the first three consecutive patients. According to our experiences, the product helps to improve movement performance. Side effects are mainly reversible elevations of liver enzymes and serum troponin-I levels, thrombocytopenia and granulocytopenia. Therefore, we found that it is important to monitor patients closely on a longterm basis in order to detect and eliminate side effects early.

Keywords: adenovirus-associated gene therapy, motor function, nusinersen, onasemnogene abeparvovec, spinal muscular atrophy, Werdnig-Hoffmann disease

Mikos B, Gergely A, Balázsfi R, Bányász E, Gyömörei B, Hantos M, Czelecz J, Jakus R, Kárász H, Zilahy M, Molnár E, Paraicz É, Csohány Á, Szénási F, Vendégh L, Fogarasi A, Velkey GyJ. [Our initial experiences with intravenous gene therapy for spinal muscular atrophy in children]. Orv Hetil. 2020; 161(42): 1806-1816.

(Beérkezett: 2020. május 7.; elfogadva: 2020. május 29.)

\begin{abstract}
Rövidítések
AAV = adenoasszociált vírus; CHOP INTEND = Children's Hospital of Philadelphia Infant Test of Neuromuscular Disorders; DNáz = dezoxiribonukleáz; DNS = dezoxiribonukleinsav; $\mathrm{EKG}=$ elektrokardiográfia; GGT = gamma-glutamiltranszferáz; GOT = glutamát-oxálacetát-transzamináz; GPT = glutamát-piruvát-transzamináz; HFMSE = Hammersmith Functional Motor Scale; HIV = humán immundeficientia-vírus; it. = intrathecalis; iv. = intravénás; $\mathrm{LDH}=$ laktát-dehidrogenáz; mTOR (mammalian target of rapamycin) a rapamicin célpontja emlősökben; NIV = (non-invasive ventilation $)$ nem invazív légzéstámogatás; se = szérum; SMA = spinalis muscularis atrophia; $\mathrm{SMN}=$ (survival motor neuron $)$ túlélő motoros neuron; Thr $=$ thrombocyta; TLR9 $=($ Toll-like receptor 9$)$ Toll-szerú receptor-9; USA = (United States of America) Amerikai Egyesült Államok
\end{abstract}

A spinalis muscularis atrophia (SMA) az 5q-kromoszómához kötött gyógyíthatatlan, progresszív neurodegeneratív betegség, a gyermekkori halálozások gyakori genetikai oka. Az SMNI- (survival motoros neuron) gén biallél deletiója és/vagy mutációja okozza. Tünetei annál súlyosabbak, minél kevesebb az SMN2- („tartalék”) gén kópiaszáma $[1,2]$.

A Werdnig-Hoffmann-kórként ismert SMAI esetén a legtöbbször két SMN2-kópiával rendelkezik a beteg. Féléves kor előtt kezdődő progresszív motorosfunkcióhanyatlás, 8-10 hónapos kortól permanens respirátordependencia jellemzi, következménye a legtöbbször csecsemőkori halál [3-5]. 2016 előtt - oki terápia hiányában - lehetôségeink a súlyos izomgyengeség és a mozgásképtelenség miatti szövődmények késleltetésére, illetve ellátására szorítkoztak; a progresszió és a legsúlyosabb formákban a korai halál elkerülhetetlen volt [1, 6-8].

Napjainkban a terápiás törekvések az SMN-fehérje szintjének növelésére irányulnak, aminek első lehetôsége az intrathecalis (it.) antisense oligonukleotid nuszinerszen volt. 2018 óta hazánkban finanszírozott, rendszeresen adandó készítmény, bizonyítottan javítja a betegek életkilátásait és életminőségét [9].
A 2019-ben forgalomba került onaszemnogén abeparvovek kétévesnél fiatalabb SMAl-betegek kezelésére intravénásan (iv.) alkalmazható, fenntartó ismétlést hoszszú évekig nem igénylő, biztató eddigi tapasztalatokkal rendelkező génterápia [1]. Európai engedélyeztetése ez év májusáig váratott magára. Dolgozatunkban a Magyarországon elsőként kórházunkban onaszemnogén abeparvovek terápiában részesült öt gyermek közül azzal a három gyermekkel kapcsolatos tapasztalatainkról számolunk be, akiknél már rendelkezünk utánkövetési adatokkal.

\section{Betegek és módszer}

Molekuláris genetikai vizsgálattal igazolt SMAI miatt előzetesen nuszinerszen- (Inj. Spinraza; Biogen, Cambridge, MA, USA) terápiában részesült három gyermek szülei a Magyarországi Református Egyház Bethesda Gyermekkórházától kérték az onaszemnogén abeparvovek (Inj. Zolgensma; AveXis, Chicago, IL, USA) iv. génterápia kivitelezését. A kezelési költségeket öneróből - többnyire társadalmi gyújitésből - fedezték.

Európai és hazai törzskönyvezés hiányában kórházunk munkacsoportot hozott létre orvosszakmai protokoll kidolgozására, az indikációnak, a kontraindikációnak, a beadási módnak, az engedélyeztetésnek, a jogi feltételeknek a tisztázására és megteremtésére és a lehetséges szövődmények elhárítására. Ehhez a gyártó és forgalmazó cég rendelkezésünkre bocsátotta az alkalmazási előiratot, és képzést biztosított a terápia kizárási kritériumairól (1. táblázat). Az Emberi Erőforrások Minisztériumának Egészségügyért Felelős Államtitkárságával, az Országos Gyógyszerészeti és Élelmezés-egészségügyi Intézet, a Nemzeti Egészségbiztosítási Alapkezelő és a Hungaropharma Zrt. képviselőjével, valamint a Szakmai Kollégiummal folytatott konszenzus alapján etikai bizottságunk jóváhagyásával született elvi döntés a génterápia vállalására.

Az előkészületeket, a gyógyszerbeadást és az utánkövetést a gyári előirat szerint végeztük. 


\section{1. táblázat $\mid$ Az onaszemnogén abeparvovek terápia kizáró okai}

Az aktív vírusfertőzés jelei (hurut, láz, hányás, hasmenés stb.)

Génmutációs vizsgálattal nem igazolt a spinalis muscularis atrophia

A beteg invazív lélegeztetést igényel

HIV-, hepatitis A és hepatitis C szerológiai pozitivitás

$1: 50$ feletti anti-AAV9-titer (ELISA)

Klinikailag szignifikáns májenzim-emelkedés

Szérumbilirubin $\geq 3,0 \mathrm{mg} / \mathrm{dl}(\geq 51,3 \mu \mathrm{mol} / \mathrm{l})$

Szérumkreatinin $\geq 1,8 \mathrm{mg} / \mathrm{dl}(\geq 159,12 \mu \mathrm{mol} / \mathrm{l})$

Szérumhemoglobin $<8 \mathrm{~g} / \mathrm{dl}(<80 \mathrm{~g} / \mathrm{l})$ vagy $>18 \mathrm{~g} / \mathrm{dl}(>180 \mathrm{~g} / \mathrm{l})$

Fehérvérsejtszám >20 G/1

$\mathrm{AAV}=$ adenoasszociált vírus $;$ ELISA $=$ enzimhez kapcsolt immunszorbens-vizs gálat; GGT = gamma-glutamil-transzferáz; HIV = humán immundeficientiavírus

Ellenjavallat hiányában és a gyógyszer árának a gyártóhoz utalása után került sor a gyermekek testsúlyához és életkorához adaptált egyéni adag gyártására. A készítmény Magyarországra szállítása speciális körülmények között, szigorú biztonsági előkészületek mellett zajlott. A megérkezését követő napon a gyermekeket steril, izolált kórteremben helyeztük el, és per os megkapták az 1 $\mathrm{mg} / \mathrm{ttkg} / \mathrm{nap}$ prednizolont, valamint $1 \mathrm{mg} / \mathrm{ttkg} / \mathrm{nap}$ famotidint. Két biztonságos perifériás vénakanült helyeztünk be, a gyógyszer beadására és az esetleges akut szövődmény azonnali ellátására. Másnap a szteroid és a famotidin megismétlése, a kiolvasztott ampullák 'laminar flow box'-ban végzett, közös fecskendőbe szívása után 1 órás infúzióban adtuk be a hatóanyagot. Mindez folyamatos, többparaméteres, nem invazív monitorozás mellett történt, amelyet a kezelés után még 24 órán át fenntartottunk. A tünet- és panaszmentes gyermekeket a 3 . napon budapesti tartózkodási helyükre bocsátottuk el, annak érdekében, hogy probléma esetén mielőbb elérjék kórházunkat. Követésüket az előirat szerint végeztük (2. táblázat). A szteroidot az első hónapban változatlan dózisban, majd 28 nap alatti fokozatos leépítéssel terveztük. A vizsgálatokat a monitorozott paraméterek aktuális értékétől függően kiegészítettük góckutatással, kardiológiai szakvizsgálattal és a mozgásteljesítmény mérésével. Az észlelt mellékhatásokat jelentettük a gyártónak.

\section{Esetismertetések és eredmények}

Az első beteg (A) öthetes korától gyógytornában részesült nyaki izomhypotonia miatt. Négy hónapos korában fokozódott a nyaki tónustalanság, és csökkent az alsó végtagok mozgásaktivitása. Az SMA1 genetikai igazolása 8 hónapos korban történt. A 41. élethéten kapta az első nuszinerszent, a 3. dózis után éjszakai nem invazív légzéstámogatással (NIV) kiegészítve. Hat dózis után CHOP INTEND- (Children's Hospital of Philadelphia Infant Test of Neuromuscular Disorders) értéke a 23 hetes életkori 40 pontról 60-ra emelkedett. A 88. élethéten történt az iv. génterápia, ekkor HFMSE- (Hammersmith Functional Motor Scale) pontszáma 9 volt. 15 hét múlva motoros funkcióinak előrehaladása meggyőző, axiális és végtagi hypotoniája minimálisra csökkent, egyedül biztosan megül, kapaszkodva önállóan ülésbe húzza magát, kerekes székkel ügyesen közlekedik. Háton fekve lábait nyújtva képes emelni. Harang alakú mellkasi deformitása már a nuszinerszen adásakor jelentősen mérséklődött, a NIV naponta 1-2 órán át folytatódik.

A per os szteroid beadása után korán jelentkezett intolerancia (öklendezés, hányás) rectalis adásra megszűnt. Átmeneti étvágytalanságot és súlycsökkenést követően 10 hét alatt 440 g-ot gyarapodott.

A második beteg (B) 4 hónapos korban fejét hason fekve tartotta, 8 hónaposan kúszni kezdett, de lábait nem használta. 6 hónapos korában tûnt fel a felső végtagok gyenge antigravitációs mozgása és az alsó végtagi areflexia. Az SMN1-gén homozigóta deletiójának egyéves korában történt kimutatását követően két hónappal kezdődött a nuszinerszentelítés, a 3. dózis után éjszakai NIV-vel kiegészítve. Az 5. dózis után, 56 pontos CHOP INTEND- és 13 pontos HFMSE-érték mellett, 99 hetes korában került sor az iv. génterápiára, szövődménymentesen.

A neurológiai vizsgálat 11 hét múlva lényeges mozgásfejlődést állapított meg a normotoniássá vált felső végtagokban, melyek evőeszköz önálló kézbevételére, legókockák összeillesztésére képessé váltak. Ülésbe húzva megtámasztva megül, kerekes székkel közlekedik. Átmeneti étvágycsökkenés és fogyás után 11 hét alatt 400 g-ot gyarapodott. NIV-ben napi 1-2 órán át részesül.

A harmadik betegnél (C) megszületésétől észleltek generalizált, alsó végtagi túlsúlyú izomhypotoniát. Az

2. táblázat | Betegkövetés az intravénás génterápia után

\begin{tabular}{|c|c|c|c|c|c|c|c|c|c|c|c|c|c|}
\hline \multirow[t]{3}{*}{ Vizsgálat } & \multirow[t]{3}{*}{ Kiindulási } & \multicolumn{12}{|c|}{ A gyógyszerbeadás után eltelt időszak } \\
\hline & & \multicolumn{4}{|c|}{1 hónap } & \multicolumn{4}{|c|}{2 hónap } & \multicolumn{4}{|c|}{3 hónap } \\
\hline & & 1. hét & 2. hét & 3. hét & 4. hét & 5 . hét & 6 . hét & 7. hét & 8 . hét & 9. hét & 10. hét & 11. hét & 12. hét \\
\hline Májfunkció & $\mathbf{x}$ & $\mathrm{x}$ & $\mathrm{x}$ & $\mathrm{x}$ & $\mathrm{x}$ & & $\mathrm{x}$ & & $\mathrm{x}$ & & $\mathrm{x}$ & & $\mathrm{x}$ \\
\hline Thr-szám & $\mathbf{x}$ & $\mathbf{x}$ & $\mathbf{x}$ & $\mathbf{x}$ & $\mathbf{x}$ & & $\mathbf{x}$ & & $\mathbf{x}$ & & $\mathbf{x}$ & & $\mathbf{x}$ \\
\hline Szérum-troponin-I & $\mathbf{x}$ & $\mathbf{x}$ & $\mathbf{x}$ & $\mathbf{x}$ & $\mathbf{x}$ & & & & $\mathbf{x}$ & & & & $\mathbf{x}$ \\
\hline
\end{tabular}

Thr $=$ thrombocyta 


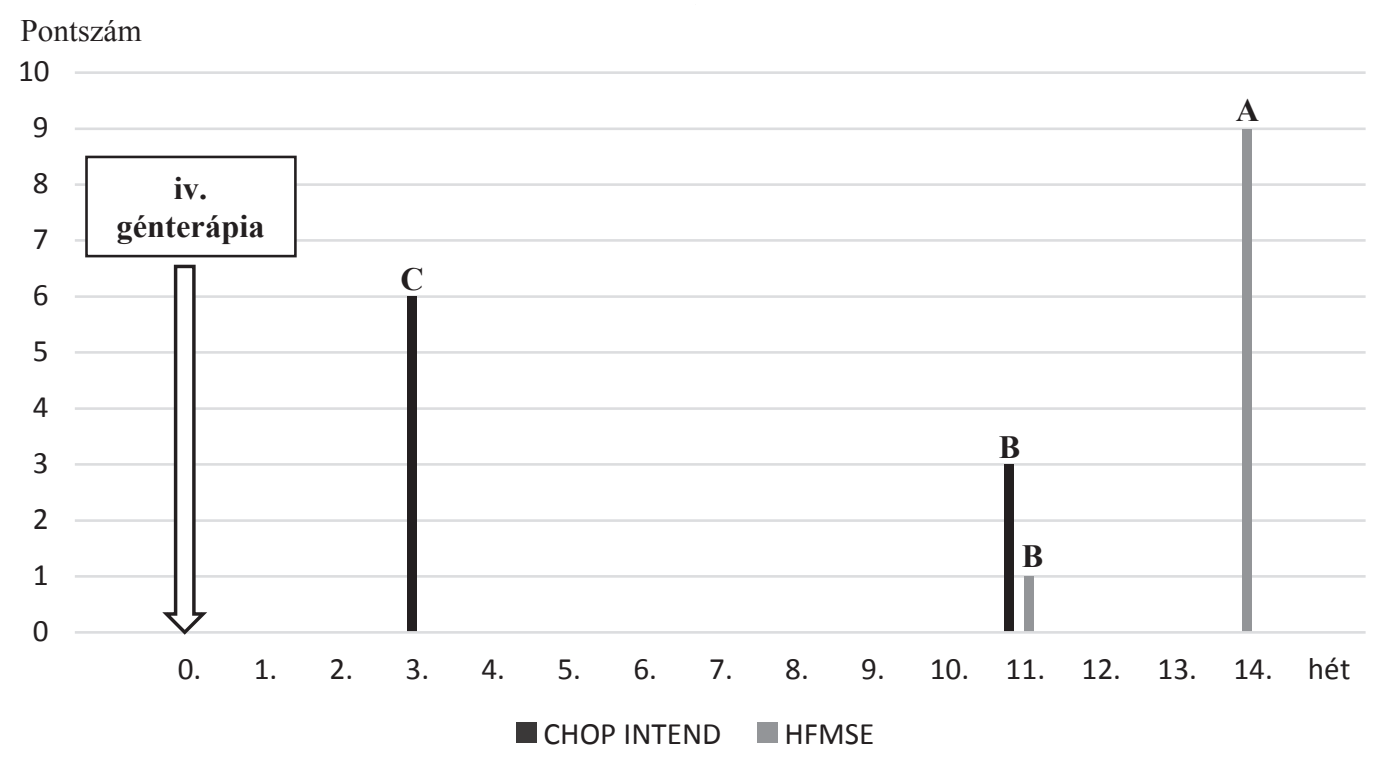

A: első beteg; B: második beteg; C: harmadik beteg

1. ábra

A CHOP INTEND- és a HFMSE-pontszám-emelkedés mértéke a génterápia után

CHOP INTEND $=$ Children's Hospital of Philadelphia Infant Test of Neuromuscular Disorders; HFMSE $=$ Hammersmith Functional Motor Scale

SMAl genetikai igazolása féléves korában történt. Hét nuszinerszendózis mellett progrediáló nyelészavara miatt 10 hónapos korától enteralis szondatáplálásban, 22 hónapos korától éjszakai NIV-ben részesül. Mozgásteljesítményének javulása a lábak felhúzásában és a karok fej fölé emelésében nyilvánult meg. Az iv. génterápia előtt nyelvfasciculatio, fejtartási képtelenség, igen renyhe felsó végtagi saját reflexek és alsó végtagi, valamint hasbőrareflexia, generalizált izomhypotonia állt fenn. CHOP INTEND-értéke 26 pont volt.

Programunkba vétele után optimalizáltuk a NIV-paramétereit, és súlyos alultápláltság miatt táplálástámogatást kezdtünk. 101 hetes korában részesült iv. génterápiában.

Két hét múlva karjait emelve tárgyak után célzottan nyúl, próbálja megfogni, hasra fektetéskor lábait térdben hajlítva megemeli, 230 g-ot gyarapodott. Az éjszakai NIV folytatódik.

A mozgásteljesítmény az iv. génterápia után az A gyermeknél a HFMSE-skálán 14 hét alatt 9 ponttal, a B gyermeknél 11 hét múlva a CHOP INTEND 3, a HFMSE 1 ponttal, a C beteg CHOP INTEND-értéke 3 hét alatt 6 ponttal emelkedett (1. ábra).

$\mathrm{Az}$ iv. génterápiát követő héten mindhárom gyermek belázasodott (A és B beteg: $38,8^{\circ} \mathrm{C}, \mathrm{C}$ beteg: $38,4{ }^{\circ} \mathrm{C}$ rectalis csúcshómérséklet). Az A betegnél a további 12 hétben még 3 alkalommal lépett fel l-2 napig tartó láz, enyhe felső légúti infekció kapcsán. A B gyermeknél a 12. héten a leukocytosist indukáló otogén infekció jól reagált antibiotikum- és tüneti terápiára. A C gyermeknél az 1 . héten 3 napon át $38,4{ }^{\circ} \mathrm{C}$-ig emelkedő rectalis hőmérsékletet infekt tünetek nem kísérték, azóta láztalan.
Az egy hét múlva végzett kontroll során mindhárom betegnél thrombocytopenia, szérum (se)-laktát-dehidrogenáz (LDH)- és se-glutamát-oxálacetát-transzamináz (GOT)-emelkedés jelentkezett.

A thrombocytopenia mélypontja változó volt (A beteg: $72 \mathrm{G} / \mathrm{l}$, B beteg: $88 \mathrm{G} / \mathrm{l}$, C beteg: $35 \mathrm{G} / \mathrm{l}$; referenciatartomány: 150-400) (2. ábra), egy hét múlva mindhármuknál rendeződött.

Az A betegnél az LDH 1193 U/l csúcsértéke (referenciatartomány: 280-620) kettő, a B betegnél az 1229 $\mathrm{U} / \mathrm{l}$ érték három hét alatt normalizálódott, bár a 12 . héten átmenetileg kissé ismét emelkedett. A C beteg magas (1317 U/1) kezdeti értéke 2 hét alatt még nem érte el a normáltartományt $(812 \mathrm{U} / \mathrm{l})$ (3. ábra).

A GOT egyidejúleg mindhárom gyermekben meghaladta a felső határt (A beteg: 105, B beteg: 82 , C beteg: $104 \mathrm{U} / \mathrm{l}$; referenciatartomány: 0-60). Az A betegnél a génterápia után 6 héttel ismét kórossá vált, és a 10. héten meghaladta a felső határ kétszeresét (123 U/1), ezért a már befejezett szteroidterápiát visszaállítottuk napi $\mathrm{I} \times \mathrm{l}$ $\mathrm{mg} / \mathrm{ttkg}$ dózisban. Két hét múlva - a normálérték birtokában - elkezdhettük a fokozatos szteroidleválasztást további négy hét alatt. Így az immunszuppresszió időtartama a tervezett 60 nap helyett 102 napra nyúlt. A B betegnél az extrém emelkedés $(659 \mathrm{U} / \mathrm{l})$ egy hét alatt negyedére, majd a további hetekben normálközeli értékre csökkent, a szteroiddózis módosítása nem vált szükségessé. A C gyermeknél az emelkedést szorosan követjük.

A kóros se-glutamát-piruvát-transzamináz (GPT) a 2. és a 6. hét között volt jellemző. Extrém értéket $(492$ U/1; referenciatartomány: 0-52 U/1) a 2. héten mutatott ugyanannál a betegnél (B), akinél egyidejúleg kiugróan magas GOT- és $81 \mathrm{U} / 1$ se-gamma-glutamil-transz- 


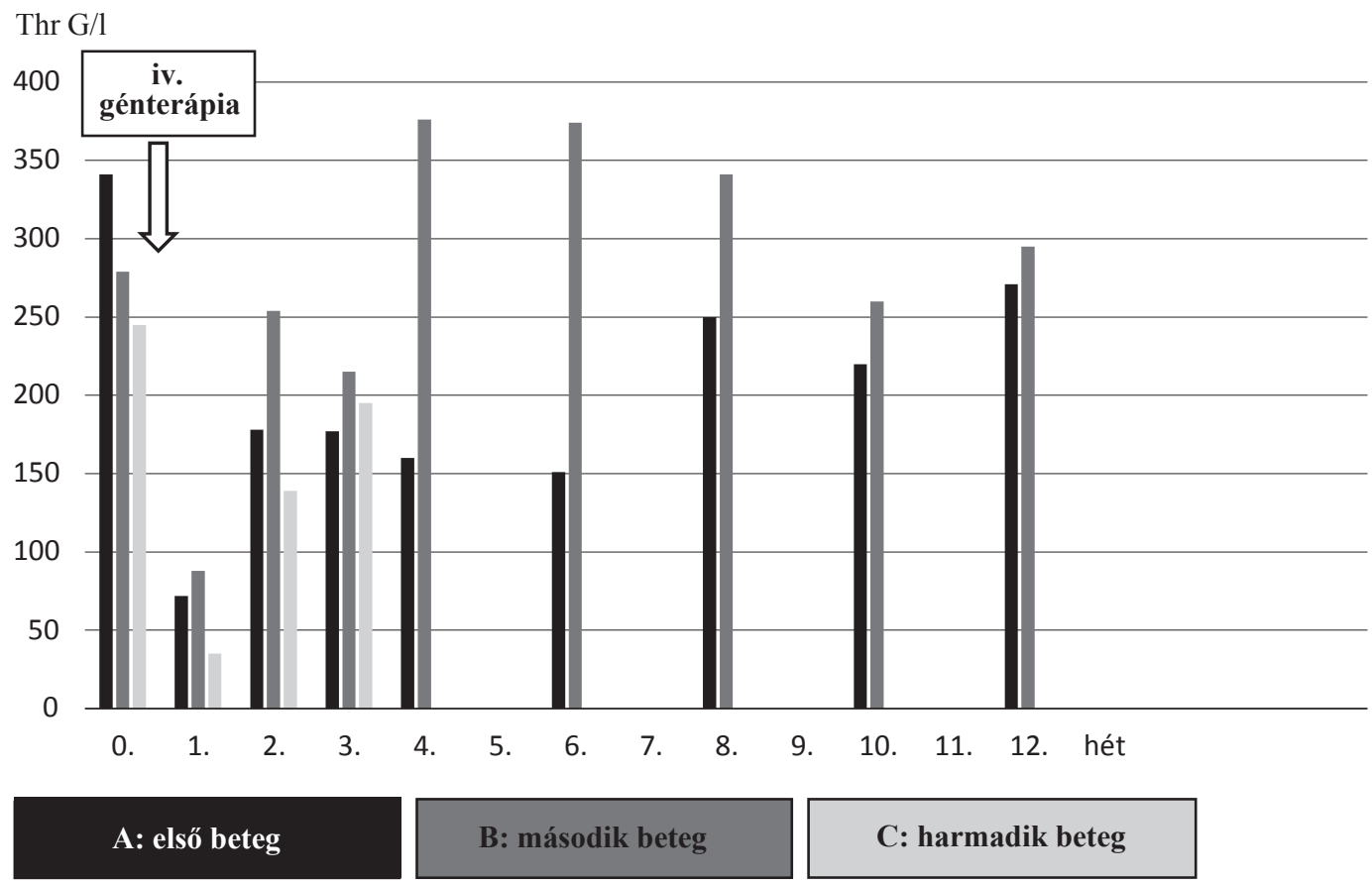

Thr = thrombocytaszám

2. ábra |A thrombocytaszám változása a génterápia után

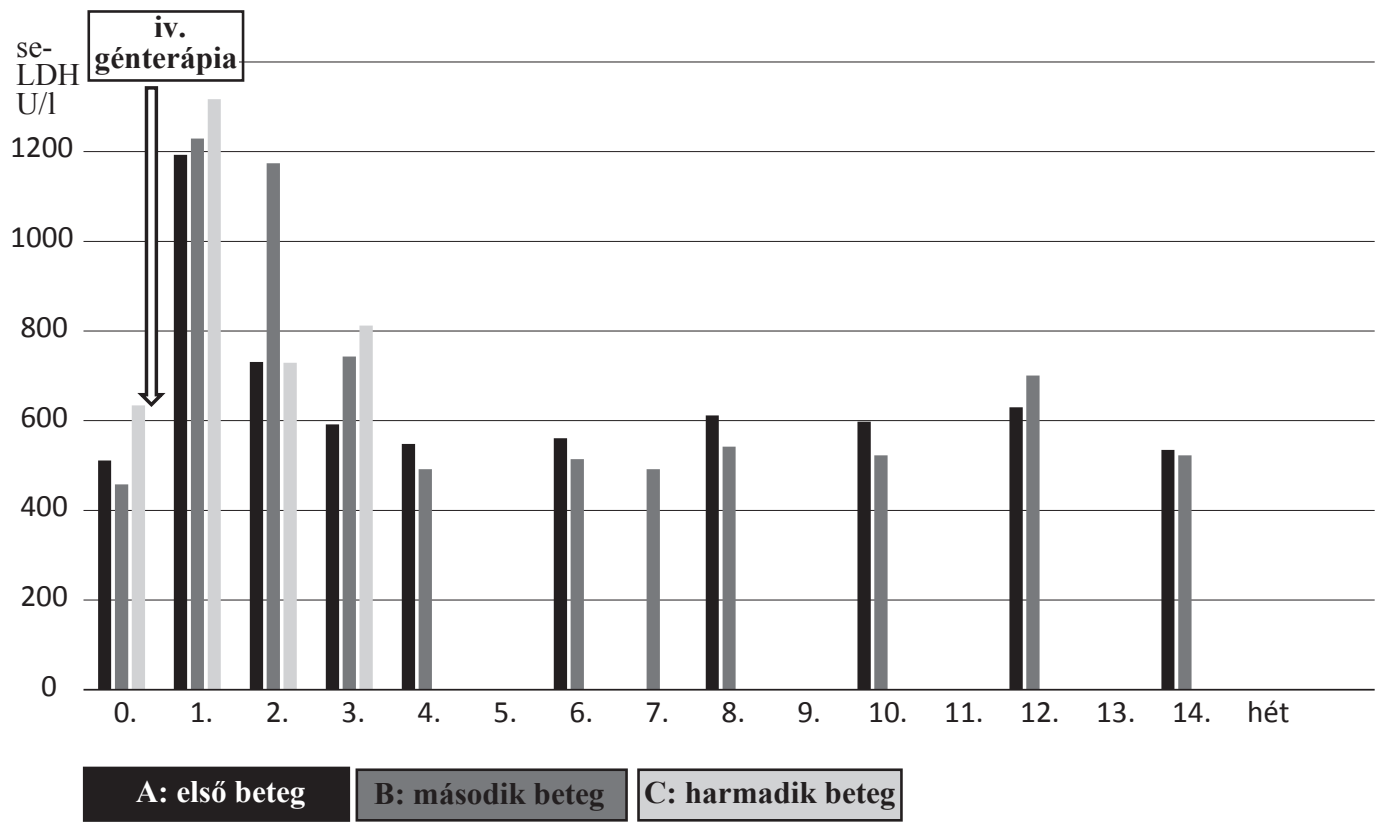

se-LDH = szérum-laktát-dehidrogenáz

3. ábra

| A szérum-LDH változása a génterápia után

feráz (GGT)-szintet (referenciatartomány: 0-40) mértünk. Az A betegnél a 6. és 10. heti magasabb GPT (62, illetve $88 \mathrm{U} / \mathrm{l}$ ) átmenetinek bizonyult, a $\mathrm{C}$ gyermeknél 3 hét után kissé meghaladta a felső határt $(65$ U/1) (4. ábra). A GGT az A és a C betegnél a normáltartományban maradt.
A leukopenia két gyermeknél két hét elteltével volt a legkifejezettebb (A beteg: 3,7; C beteg: 4,6 G/1 fehérvérsejtszám; referenciatartomány: 6,0-13,5). Az A betegnél a 10. hétig elhúzódott, a $\mathrm{B}$ betegnél későbbi, enyhébb és átmeneti volt (4. hét: 5,6 G/1), a $\mathrm{C}$ gyermeknél egy hét múlva 5,7 G/1-re emelkedett. A súlyosabb leu- 


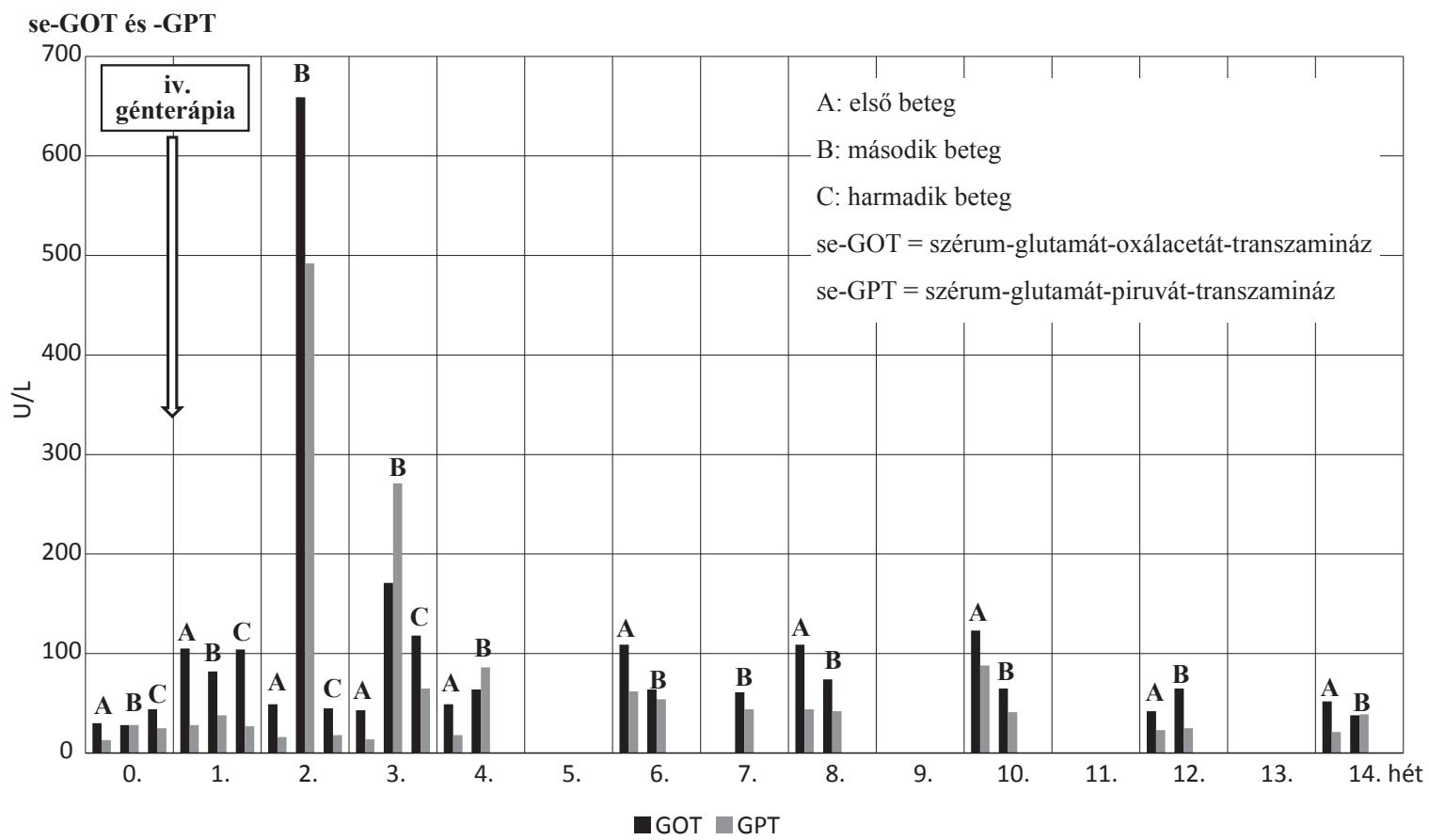

4. ábra

| A szérum-GOT és -GPT változása a génterápia után

Fvs és Gr

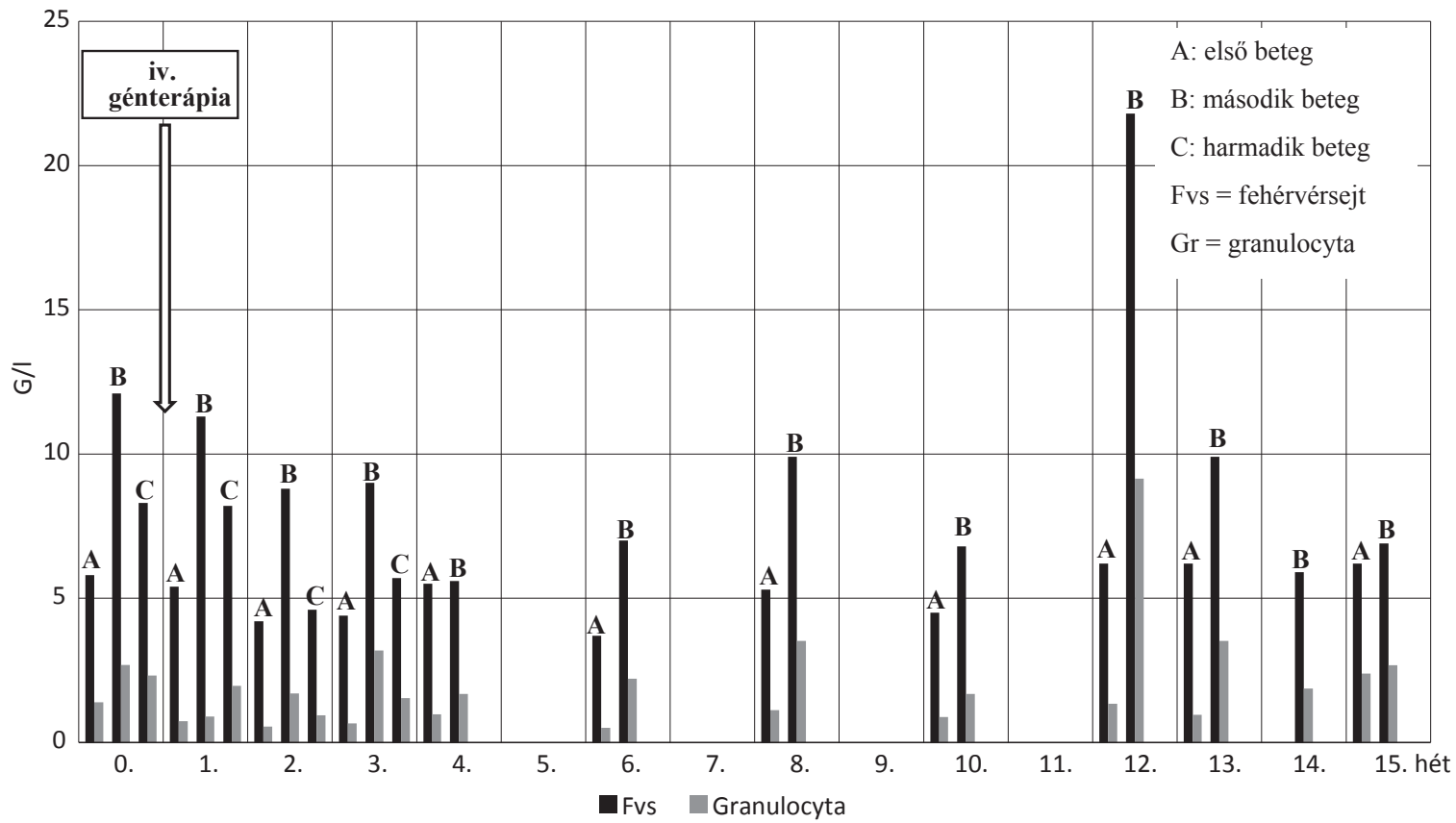

5. ábra

| A fehérvérsejt és az abszolút granulocytaszám változása a génterápia után

kopeniához súlyosabb és tartósabb granulocytopenia társult (mélypont: A beteg: 0,51 G/1; B beteg: 0,90; C beteg: 0,94; referenciatartomány: 1,9-8,0 G/1). Az A betegnél a 14 hét követés során hétszer mértünk 1000 G/1 alatti abszolút granulocytaszámot. A B betegnél a késői szakban otitis kapcsán a leukocytosist 9,15 G/1 granulocytaszám kísérte (5. ábra).
A szérum-troponin-I a génterápia után egy héttel mindhárom gyermeknél emelkedő tendenciát mutatott. Az A betegnél nem haladta meg a normáltartományt, és értéke a 6 . hétre a negyedére csökkent. A B betegnél ugyanakkor a 6. héten vált kórossá (csúcsérték a 7 . héten: $38,5 \mathrm{ng} / 1$, normál felső határ: $34,2 \mathrm{ng} / \mathrm{l}$ ). A C betegnél már a háromhetes kontrollnál meghaladta a nor- 


\section{se-tr-I \\ ng/l}

40

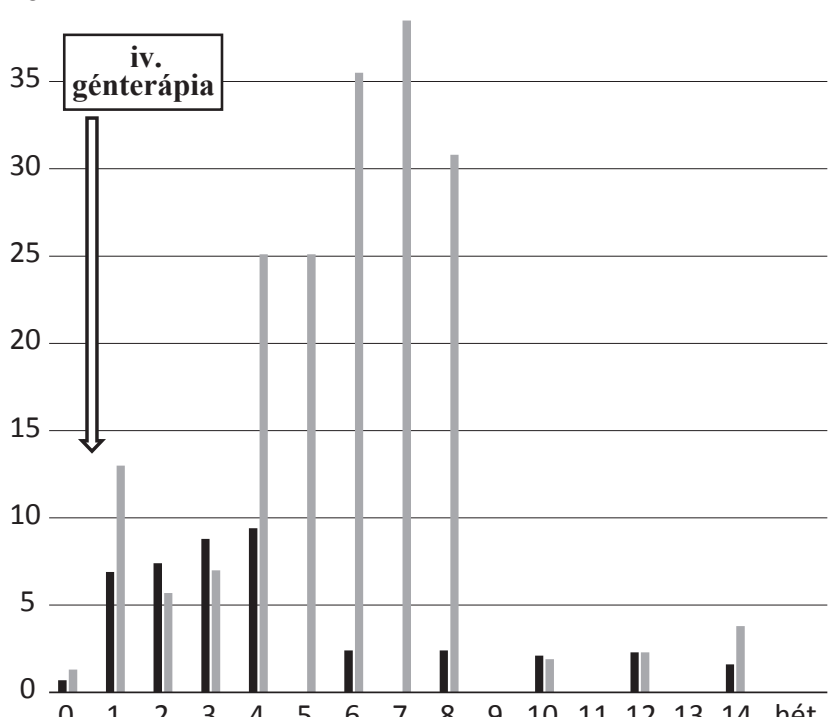

A: elsó beteg

\section{B: második beteg}

se-tr-I = szérum-troponin-I

6. ábra | A szérum-troponin-I-szint változása a génterápia után

málhatárt $(23,5 \mathrm{pg} / \mathrm{ml}$, referenciatartomány $\leq 19,00 \mathrm{pg} /$ $\mathrm{ml}$ ) (az előző két betegtől eltérő referenciaérték miatt az ábrán nem szerepel) (6. ábra). Szoros kardiológiai ellenőrzés mellett ennek klinikai konzekvenciája egyik gyermeknél sem igazolódott.

\section{Megbeszélés}

Az SMA a gerincvelő ventralis szarvában elhelyezkedő alfa-motoros neuronok pusztulásával, denervációval és izomatrophiával járó, autoszomális recesszív öröklődésű betegség. Oka a motoros neuronok zavartalan múködőképességét biztosító SMN-fehérje képződéséért felelős SMN1-gén deletiója vagy mutációja. Amennyiben új duplikáció révén nem keletkezik az SMN2-génből kópia, már a magzati korban halálos. Legfeljebb 2 kópia esetén a súlyos, progresszív légzési elégtelenség általában 2 éves kor elött halálhoz vezet. Az SMN2-kópiaszám befolyásolja a betegség fenotípusát. Több kópiaszám mellett az izomfunkció-vesztés üteme változó, az életkorral fokozódik a mozgáskorlátozottság, a mellkasi és gerincdeformitás. A besorolás alapja a legnagyobb önálló mozgásképesség (fekvő, ülő, járó, felnőtt) (3. táblázat) [2, 3, 5, 6, $10,11]$.

A genetikai háttér feltárása és a korszerú diagnosztika meghatározó előrelépés volt a génterápiához. Napjainkban két innovatív lehetőséggel rendelkezünk az SMA kezelésére. Alkalmazásuk fó kritériuma az 5q-kromoszóma-rendellenesség genetikai igazolása. A génterápia a preklinikai stádiumban lenne optimális, a neuronpusztulás előrehaladásával ugyanis csökken a terápiás effektus.

A szintetikus nuszinerszen a hiányzó $S M N 1$-génhez hasonló SMN2-génszakasz manipulációjával segíti elő a múködőképes fehérje képződését a motoros neuronokban, ahova it. beadás után gyorsan penetrál. Átmeneti hatása miatt 4 telítő dózis után 4 havonta fenntartó adagolás szükséges. Az egyszeri dózis életkortól és testtömegtől függetlenül $12 \mathrm{mg}$. Legalább két $S M N 2$-kópiaszám meglétekor mintegy 70\%-os hatékonysággal emeli meg az SMN-fehérje-szintet [6, 9, 12].

3. táblázat |Az SMA típusai

\begin{tabular}{|c|c|c|c|c|}
\hline Jellemzők & $\begin{array}{l}\text { SMA1 } \\
\text { Werdnig-Hoffmann-betegség }\end{array}$ & $\begin{array}{l}\text { SMA2 } \\
\text { Intermedier típus }\end{array}$ & $\begin{array}{l}\text { SMA3 } \\
\text { Kugelberg-Welander-betegség }\end{array}$ & $\begin{array}{l}\text { SMA4 } \\
\text { Felnőttkori típus }\end{array}$ \\
\hline Öröklésmenet & Autoszomális recesszív & Autoszomális recesszív & Autoszomális recesszív & \\
\hline Az érintett génszakasz & $5 \mathrm{ql} 1.2-13.3$ & $5 \mathrm{ql1} .2-13.3$ & $5 q 11.2-13.3$ & \\
\hline A tünetek kezdete & $\begin{array}{l}0-6 \text { hó } \\
\text { az intrauterin } 3-6 \text {. hónapban } \\
\text { megindul az izomsorvadás }\end{array}$ & 7-18 hó & $>1,5$ év & 2-3. évtized \\
\hline Mozgás-teljesítmény & Fekvő & Ülőképes & Járóképes & Járóképes \\
\hline Halálozás & 2-3 éves korig & $\begin{array}{l}2 \text { éves kor után csak néhány } \\
\text { beteg éri meg a felnőttkort }\end{array}$ & Felnőttkorban & $\begin{array}{l}\text { Felnőttkorban } \\
\text { Az élettartamot nem } \\
\text { rövidíti meg }\end{array}$ \\
\hline Tünetek & $\begin{array}{l}\text { Fasciculatio a vázizomzatban } \\
\text { és a nyelvben } \\
\text { Gyenge sírás, köhögés és } \\
\text { fejkontroll } \\
\text { Légzési nehézség } \\
\text { Gyakori hurut }\end{array}$ & $\begin{array}{l}\text { Nyelvatrophia, fasciculatio, } \\
\text { izomsorvadás, reflexkiesések, } \\
\text { scoliosis } \\
\text { Súlyos légzészavar } \\
\text { Lassú súlynövekedés } \\
\text { Erőtlen köhögés, kézremegés, } \\
\text { ízületi kontraktúrák }\end{array}$ & $\begin{array}{l}\text { Változó izomgyengeség } \\
\text { A combizomzat atrophiája } \\
\text { fasciculatióval, reflexkieséssel, } \\
\text { ízületi lazaság } \\
\text { Izomgörcs } \\
\text { A járóképesség elvesztése } \\
\text { felnőttkorban }\end{array}$ & $\begin{array}{l}\text { A proximális izmok } \\
\text { gyengesége } \\
\text { Változó súlyosságú } \\
\text { járászavar } \\
\text { Lassú progresszió }\end{array}$ \\
\hline
\end{tabular}

SMA = spinalis muscularis atrophia 
Az onaszemnogén abeparvovek AAV- (adeno-associated virus) génterápia. Hatóanyaga az SMNl-transzgén, a természetes génhez hasonló kétszálú DNS. A sejtek episomájába jutva genetikai instrukciókat ad az SMN-fehérjét termelő transzgén aktiválódásához, így folyamatosan, éveken át megfelelő mennyiségben képződik a túlélő fehérje. Hatása tartós, bár a sejtek dezoxiribonukleáz (DNáz) enzimje elbonthatja, ezért a fehérjeszintézis fokozatos csökkenése lehetséges 10-15 év után [1]. A készítményt az Egyesült Államokban 2019-ben, Európában 2020 májusában hagyták jóvá [13].

Szisztémás adásakor mintegy „megfertőzzük” a szervezet minden sejtjét, ezért mellékhatása a máj, a vese és a szívizom károsodása, thrombocytopenia, anaemia, idegrendszeri görcskészség lehet. A kívánt hatás eléréséhez ugyanis viszonylag nagy dózis szükséges, mert az immunválasz stimulálása antikapszid- és antitranszgénimmunitás indukálásával csökkentheti hatását.

Az immunreakció megelőzésére történik az immunszuppresszív terápia szteroiddal.

Vizsgálatok folynak továbbá Toll-like receptor 9 (TLR9-) modulálással, B-sejt-depléciót indukáló rituximabbal, plazmasejt-reaktivációt gátló bortezomibbal, a mTOR-t (mammalian target of rapamycin) moduláló rapamicinnel, transzgénspecifikus regulátorokkal és a plazmaferézissel [14-17].

A hatóanyag adenovírus-vektorhoz kötött, hatásosságának feltétele az alacsony anti-AAV9-titer. A beadás előtt 30 napnál régebbi értéke már nem tükrözi a beteg aktuális, AAV elleni antitestszintjét. Az előírt 1 : 50 alatti titerérték mellett is közöltek immunreakcióra utaló központi idegrendszeri szövődményt [18, 19]. Kutatják az AAV kapszid és transzgén elleni immunválasz-csökkentésének további lehetőségeit, ami javíthatná a hatáserősséget és a hatástartamot [20].

A terápia hatékonyságának objektív megítélésére a hazai irányelv a CHOP INTEND- és/vagy a HFMSE-skálával történő mozgásstatus-felmérést javasolja 4 havonta [6]. A CHOP INTEND 16 szempont alapján méri a mozgásteljesítményt a nem ülőképes, két évnél fiatalabb betegeknél [6, 21]. A HFMSE a 2 éves kort betöltött SMA-betegeknél alkalmazható skála $[6,22]$.

$\mathrm{Az}$ 1. fázisú START klinikai vizsgálatban 15, félévesnél nem idősebb SMAl-beteg kapta a készítményt egyszeri iv. infúzióban. A kétéves utánkövetés során egyetlen gyermek sem igényelt permanens lélegeztetést, a nem kezelt betegeknél ez az arány mindössze $8 \%$ volt. 9 gyermek legalább 30 mp-ig tudott ülni, kettő állni és járni segítség nélkül [23].

A 3. fázisú STRIVE klinikai vizsgálatban 0,5-5,9 hónapos $S M A 1$-csecsemők részesültek iv. génterápiában. Az SMAI természetes lefolyása esetén 14 hónapos korban 25\%-uk nem igényelt folyamatos légzéstámogatást, itt mindössze egy beteg. Egy hónappal később a CHOP INTEND átlagosan 6,9 ponttal emelkedett, kezelés nélkül folyamatosan csökkent [23].
Mindkét vizsgálatban a májenzim-emelkedés és a hányás volt a leggyakoribb mellékhatás.

Egy tanulmány az SMAI-ben szenvedő csecsemőknél alkalmazott AAV-génterápia hatékonyságát hasonlította össze egy természetes kórlefolyású, valamint egy egészséges csecsemőkből álló csoporttal. A 24 hónapos túlélés a kezelt csoportban 100, a nem kezelt betegeknél 38\%os volt. Az átlagos kiinduló CHOP INTEND-pontszám 28,2-ről 56,5-re növekedett, kezelés nélkül 20,3-ról 5,3ra romlott $[1,23]$.

A különböző, részben még folyamatban lévő vizsgálatokban a 14-24 hónapos utánkövetés során a betegek 64-91,7\%-ánál alakult ki önálló fejtartási és/vagy legalább $10 \mathrm{~s}$ ülőképesség, és életkoruktól függően különböző mérföldköveket értek el a mozgásteljesítményben [24-26] (4. táblázat).

A kórházunkban kezelt három gyermeknél az iv. génterápia a szülők kérésére történt. Döntésünket a kezelés vállalásáról nehezítette az európai és a hazai törzskönyvezés hiánya, a viszonylag kevés, eddig közölt alkalmazás és a beadások óta eltelt rövid idő miatt még nem igazolható szignifikáns, hosszú távú terápiás hatás.

A készítmény zavartalan legyártása, szállítása és beadása után több mint 3 hónapon át követtük az első két beteget. A harmadik beteg 3 hete kapta meg a készítményt, hosszú távú követése folyamatban van.

Mindhárom betegünk a kevésbé optimális, kétéves életkorhoz közeli életkorban kapta a terápiát. Már a nuszinerszen mellett megindult mozgásfejlődésükben így is további mérhető javulást rögzítettünk náluk, annak ellenére, hogy lényegesen idősebb korban történt a kezelés, mint a START- és a STRIVE-vizsgálat hat hónaposnál fiatalabb csecsemőinél. Az eredmények pontosabb megítéléséhez hosszabb távú követésre lesz szükség.

A készítmény kétéves koron túl történő alkalmazása esetén a mozgásfejlődés mérföldköveinek elérési valószínűsége csökken. Bár ilyen késői életkorban az iv. adásról nincs közlés, it. adagolás kapcsán a készítményt SMA2betegek egyik csoportjánál 2 éves kor alatt, a másiknál 2-5 éves kor között alkalmazták. A fiatalabb korcsoportban lényegesen nagyobb mozgásfejlődést tapasztaltak, de az idősebb gyermekek 92\%-ánál is legalább 3, átlagosan 5,9 ponttal növekedett a HFMSE-pontszám 9,3 hónap alatt. Ez drámai javulás a hisztorikus kontrollcsoporthoz képest, 3 pont emelkedés ugyanis már lényeges funkciójavulást jelent [27].

A lehetséges mellékhatások között a leggyakoribb az étvágycsökkenés, hányinger, hányás, májenzim-emelkedés, bőrkiütés, fejfájás, légzési rendellenesség, ismeretlen előfordulással lábszárödéma, fáradtság, gyengeség, homályos látás, álmosság, izzadás, görcsjelenség. Négy tanulmány 44 betegénél a GOT- és/vagy GPT-emelkedés volt a leggyakoribb $(27,3 \%)$, amit a hányás követett 6,8\%-os gyakorisággal. További nem kívánt hatásként előfordulhat a vérzés kockázatát megnövelő thrombocytopenia, valamint a troponin-I-szint átmeneti emelkedése. Az utóbbi humán vonatkozásait egyelőre nem 
4. táblázat |Az intravénás génterápiával kapcsolatos tanulmányok eredményei

\begin{tabular}{|c|c|c|c|c|c|}
\hline \multicolumn{2}{|l|}{$\begin{array}{l}\text { A tanulmány megnevezése } \\
\text { [szakirodalmi hivatkozás] }\end{array}$} & $\begin{array}{l}\text { START (avxs-101- } \\
\text { cl-301 cohort-2) } \\
\text { 1. fázisú befejezett } \\
{[12,23,25]}\end{array}$ & $\begin{array}{l}\text { STRIVE US (avxs-101-cl-303) } \\
\text { 3. fázisú befejezett }[23,25]\end{array}$ & \multicolumn{2}{|c|}{$\begin{array}{l}\text { SPRINT (avxs-101-cl-304)* } \\
\text { 3. fázisú, folyamatban lévő } \\
{[23,25]}\end{array}$} \\
\hline \multicolumn{2}{|c|}{ Életkor az iv. génterápia időpontjában } & 0,9-7,9 hó & 0,5-5,9 hó & $\begin{array}{l}\text { A csoport: } \\
20,6 \pm 7,87 \\
(8,0-34,0) \text { nap }\end{array}$ & $\begin{array}{l}\text { B csoport: } \\
28,7 \pm 11,7 \\
(9,0-43,0) \text { nap }\end{array}$ \\
\hline \multicolumn{2}{|l|}{ Az SMA típusa } & $S M A 1$ & $S M A 1$ & \multicolumn{2}{|c|}{ Preszimptomatikus SMAI-2-3 } \\
\hline \multicolumn{2}{|l|}{$\mathrm{N}$} & 12 & 22 & 14 & 15 \\
\hline \multicolumn{2}{|l|}{ Az utánkövetés időtartama } & 24 hó & 18 hó & Átlag: 10,5 hó & Átlag: 8,7 hó \\
\hline \multirow[t]{10}{*}{$\begin{array}{l}\text { Elért mozgásteljesítmény: } \\
\text { n (\%) }\end{array}$} & Fejkontroll & $11(91,7)$ & $\begin{array}{l}\text { Átlag 6,8 hónapos korban: } \\
17(80)\end{array}$ & & \\
\hline & Hasra fordulás & $9(75 \%)$ & $\begin{array}{l}\text { Átlag 11,5 hónapos korban: } \\
12(59)\end{array}$ & & \\
\hline & Ülés $\geq 10 \mathrm{~s}$ & $10(83,3)$ & $\begin{array}{l}\text { Átlag 13,9 hónapos korban: } \\
14(64)\end{array}$ & & \\
\hline & Ülés $\geq 30 \mathrm{~s}$ & $9(75)$ & $\begin{array}{l}\text { Átlag } 12,5 \text { hónapos korban: } \\
14(63,6)\end{array}$ & $8(57,1)$ & $10(66,6)$ \\
\hline & Kapaszkodva felállás & $2(16,7)$ & $1(4,5)$ & & \\
\hline & Önálló állóképesség & $2(16,7)$ & & & $4(26,6)$ \\
\hline & Járás segítséggel & $2(16,7)$ & $1(4,5)$ & & \\
\hline & Felállás & $2(16,7)$ & $1(4,5)$ & & \\
\hline & Önálló járásképesség & $2(26,7)$ & $1(4,5)$ & $4(28,6)$ & $2(13,3)$ \\
\hline & $\begin{array}{l}\text { Elért CHOP INTEND- } \\
\text { pontszám: } \mathrm{n}(\%)\end{array}$ & $\begin{array}{l}\geq 40 \text { pont: } 9(75) \\
\geq 50 \text { pont: } 8(66,7)\end{array}$ & $\begin{array}{l}\geq 41 \text { pont: } 21(95,5) \\
\geq 50: 14(64) \\
\geq 60: 5(23) \\
\text { Átlagos pontszám-emelkedés } \\
1 \text { hó múlva: } 6,9 \\
3 \text { hó múlva: } 11,7 \\
5 \text { hó múlva: } 11,3 \\
12 \text { hó múlva: } 16,4\end{array}$ & $\begin{array}{l}\geq 60: 12(85,7) \\
\geq 50: 14(100)\end{array}$ & \\
\hline \multicolumn{2}{|l|}{ Túlélés: n (\%) } & $12(100)$ & $20(90,9)$ & $14(100)$ & $15(100)$ \\
\hline \multicolumn{2}{|c|}{ Permanens NIV-dependencia: n (\%) } & $0(0)$ & & $0(0)$ & $0(0)$ \\
\hline \multicolumn{2}{|c|}{ Nyelésképesség: $\mathrm{n}(\%)$} & $11(91,7)$ & $\begin{array}{l}19(86,3) \text { táplálás eszközös } \\
\text { segítség nélkül }\end{array}$ & $14(100)$ & $15(100)$ \\
\hline \multirow{10}{*}{$\begin{array}{l}\text { Mellékhatások: } \\
\text { n }(\%)\end{array}$} & Láz & $6(50)$ & $12(54,5)$ & $5(37,5)$ & $4(26,7)$ \\
\hline & Felső légúti infekció & $10(83)$ & $11(50)$ & $4(28,6)$ & $3(20)$ \\
\hline & Májenzim-emelkedés & $3(25)$ & $\begin{array}{l}\text { GOT-emelkedés: } 6(7,3) \\
\text { GPT-emelkedés: } 5(22,7)\end{array}$ & $12 \%$ & \\
\hline & Troponin-I-emelkedés & & & $1(7,1)$ & $2(13,3)$ \\
\hline & Thrombocytopenia & & $2(9,1)$ & $3(21,4)$ & $2(13,3)$ \\
\hline & Leukopenia & & $2(9,1)$ & & \\
\hline & Hányás & $8(67)$ & $1(4,5)$ & $3(21,4)$ & $0(0)$ \\
\hline & Súlyesés & & $2(9,1)$ & & \\
\hline & Constipatio & $7(58)$ & $9(40,9)$ & $4(28,6)$ & $0(0)$ \\
\hline & Hasmenés & $3(25)$ & $4(18,2)$ & $3(21,4)$ & $0(0)$ \\
\hline
\end{tabular}

*A SPRINT-vizsgálat (Systolic Blood Pressure Intervention Trial) még folyamatban van, a részeredmények idején a legtöbb gyermek még nem érte el a normáltartományt a motoros funkciók tekintetében.

CHOP INTEND = Children's Hospital of Philadelphia Infant Test of Neuromuscular Disorders; GOT = glutamát-oxálacetát-transzamináz; GPT = glutamát-piruvát-transzamináz; NIV = nem invazív légzéstámogatás; SMA = spinalis muscularis atrophia; SPRINT = Pre-Symptomatic Study of Intravenous Onasemnogene Abeparvovec-xioi in Spinal Muscular Atrophy (SMA) for Patients With Multiple Copies of SMN2; STRIVE = STRIVE US: ClinicalTrials.gov identifier (NCT number): NCT03306277 
ismerjük, bár állatkísérletben megfigyeltek cardiotoxicitást, illetve magasabb dózisok esetén pitvari tágulatot és thrombosist, ami felveti a keringészavarral járó mértékú szívizom-károsodás lehetőségét is [23-26].

Magunk mindhárom gyermeknél észleltünk a beadás utáni 7. napon thrombocytopeniát, illetve kóros $\mathrm{LDH}$ és GOT-emelkedést. Az utóbbi az egyik betegnél a 10. héten szükségessé tette a szteroid visszaadását, és megnyújtotta az immunszuppresszív terápia összidőtartamát. Ugyanennél a betegnél - feltehetőleg a hosszú szteroidterápia mellékhatásaként - az elhúzódó leukopeniát tartós és mély granulocytopenia kísérte. A fehérvérsejtszám csökkenésérôl az egyik tanulmány is beszámolt.

Betegeink közül két gyermeknél vált kórossá a se-troponin-I-érték, ezért több alkalommal kardiológiai vizsgálat történt. Klinikai tünetmentességük és egyebekben strukturálisan ép szív mellett myocardialis érintettség sem EKG-görbén, sem echokardiográfia során nem igazolódott.

A közölt adatokhoz hasonlóan betegeinknél is jelentkezett láz, légzőszervi infekció és étvágytalanság [12, 24].

Csak fekvő SMA-betegeknél a szakmai ajánlás előírja a NIV alkalmazását már a krónikus légzési elégtelenség tüneteinek megjelenése előtt, megelőző jelleggel, illetve hypoventilatio esetén a hypoxaemia és a hypercapnia korrigálására, valamint az ülőképes betegeknél nocturnalis hypoventilatio vagy nappali hypercapnia esetén [6]. Előnyös hatása van továbbá a mellkasi deformitás megelőzésében vagy csökkentésében. Ugyanakkor a permanens NIV-dependencia általában elkerülhető volt a génterápia korai alkalmazásával (4. táblázat).

A spontán légzés hatékonyságának javulását és a NIVdependencia mértékének csökkenését mi is megfigyeltük az első két gyermeknél, akik már csak napi 1-2 órás alkalmazását igénylik, légzésmechanikájuk javulásának és ülőképességüknek köszönhetően. A harmadik gyermek még nem ülőképes, nála rendszeresen folytatódik az éjszakai NIV.

Az izom tömegét és erejét befolyásolja a gyermekek kor- és betegségfüggő energia- és fehérjeigénye, másrészt tapasztalatunk szerint a kezelés után számolni kell átmeneti súlyvesztéssel is. Ezért a tápláltsági állapot követése és a táplálástámogatás elengedhetetlen a génterápiával elérhető legjobb hatás érdekében. Betegeinknél a későbbiekben megfigyelt gyarapodás hátterében a szteroid mellékhatásán túl a tápláltsági állapot folyamatos követése alapján hetenként korrigált táplálástámogatásnak is szerepe lehetett amellett, hogy szakirodalmi adatok igazolják a génterápia eredményeként javuló nyelésés önálló táplálkozási képesség elérését is [13, 25, 26]. $\mathrm{Az}$ oralis szteroidbevitel során észlelt hányás és étvágytalanság miatt biztonságosabbnak és tolerálhatóbbnak találtuk a rectalis adást az immunszuppresszió biztosítására.

\section{Következtetés}

Az SMAI gyors progressziójú genetikai betegség. Az innovatív genetikai kezelések javíthatják az életesélyt és az életminőséget a motoros funkciók javulása révén, ez a terápia azonban versenyfutás az idővel, hiszen a megszületés után folytatódó motorosneuron-pusztulás miatt annál kevésbé hatásos, minél később kezdjük.

$\mathrm{Az}$ első átütő előrelépést az it. nuszinerszen hozta, amit az iv. AAV-génterápia követett. Mindkét módszer a betegek gondos kiválasztásán, az előnyök és a kockázatok megfontolt mérlegelésén alapul. Napjainkban a nuszinerszen kétéves életkor felett is bevezethető, amennyiben a beteg nem igényel invazív, illetve tartós, napi 16 órát meghaladó NIV-t. Az onaszemnogén abeparvovek kétéves kor felett nem javasolt. A terápia technikai kivitelezése iv. génterápia esetén egyszerúbb, szemben az it. adandó nuszinerszennel, és nem teszi szükségessé a rendszeres fenntartó kezelést. A mellékhatásprofil szempontjából a nuszinerszen során a lumbálpunkcióhoz társuló átmeneti fej- és hátfájás, hányás, szédülés, az iv. génterápia során a reverzibilis szervspecifikus enzimemelkedések és a légzőszervi infekciók dominálnak.

Az AAV-génterápia biztonságos alkalmazásához még sok klinikai tapasztalat szükséges. Így válhat lehetővé, hogy az ismeretlentől való félelem ne gátoljon bennünket az alkalmazásában, vagy tudáshiányunk miatt ne veszélyeztessük betegeinket. Ezért esetismertetésünkkel célunk a tapasztalataink megosztása volt az Olvasókkal.

Tapasztalataink szerint rendkívül fontos a rendszeres és tartós utógondozás a korán várható májenzim-emelkedés és thrombocytopenia, hosszabb távon pedig a szívizom-nekroenzim emelkedése, az elhúzódó granulocytopenia és a fokozott infekciórizikó miatt. A mozgásteljesítmény nyomon követésére gyakori ellenőrzés szükséges a génterápia hatásfelépülésének, hatáserősségének és hatástartamának, dinamikájának objektívebb megállapítása érdekében.

A génterápia multidiszciplináris feladat. Genetikus, intenzív terápiás, neurológus, immunológus, rehabilitációs, kardiológus, pulmonológus, dietetikus, gyógytornász, klinikai gyógyszerész, labor- és infektológus specialista bevonásával és együttmúködésével végezhető hatékonyan és biztonságosan.

Reményeink szerint a közeli jövő megadja a megoldást az AAV-génterápia szövődményeinek megelőzésére, az immunreakció hatékony és mellékhatásmentes visszaszorítására és a központi idegrendszeri gyulladásos reakció kivédésére, biztonságos és hatékony terápiát nyújtva az SMA kezeléséhez; a preklinikai diagnosztika pedig a korai alkalmazással az elérhető legjobb hatás és életminőség biztosítására betegeink számára. A génmódosító és génpótló kezelés forradalmi elörelépés, azonban csak a malnutritio, sarcopenia megelőzésére irányuló táplálástámogatással, a kontraktúrák, scolisosis rehabilitációs prevenciójával és a mellkasdeformitást, thoracalis diszfunkciót kivédő légzéstámogatással együtt lehet igazán hatékony [27, 28]. 
Anyagi támogatás: A közlemény megírása, illetve a kapcsolódó kutatómunka anyagi támogatásban nem részesült.

Szerzôi munkamegosztás: M. B.: A vizsgálati paraméterek adatgyűjtése és értékelése, a következtetések levonása. G. A.: Betegkontrollok, esetek ismertetése, a légzéstámogatás irányítása. B. R. és B. E.: A kontrollvizsgálatok elvégzése és adatgyuujjtése. Gy. B.: Kardiológiai követés és értékelés. H. M.: A gyógyszeralkalmazás kidolgozása és előkészítése. Cz. J.: A táplálástámogatás megtervezése és korrigálása. K. H.: Pulmonológiai követés. J. R. és F. A.: Neurológiai követés és értékelés, a kórkép irodalmi összefoglalása. P. É. és Cs. Á.: A mozgásteljesítmény követése és rehabilitáció. Z. M., Sz. F. és V. L.: Szakirodalomkutatás. M. E.: A laboratóriumi vizsgálatok értékelése. V. Gy. J.: A szakirodalmi adatok összevetése a saját tapasztalatokkal. A cikk végleges változatát valamennyi szerző elolvasta és jóváhagyta.

Érdekeltségek: A szerzóknek nincsenek érdekeltségeik.

\section{Köszönetnyilvánítás}

Köszönetünket fejezzük ki a Bethesda Gyermekkórház valamennyi dolgozójának segítő közremúködéséért a génterápia sikeres megvalósításában, köztük a logisztikai-gazdasági háttér biztosításáért dr. Stefka Nórának, dr. Sürü Diánának és Csikós Bálint igazgatónak, ápolóinknak, dietetikusainknak, gyógytornászainknak, koordinátorunknak, orvosainknak és a diagnosztikai személyzetnek.

\section{Irodalom}

[1] Al-Zaidy SA, Kolb SJ, Lowes L, et al. AVXS-101 (onasemnogene abeparvovec) for SMAl: comparative study with a prospective natural history cohort. J Neuromuscul Dis. 2019; 6: 307-317.

[2] Feldkötter M, Schwarzer V, Wirth, R, et al. Quantitative analyses of SMN1 and SMN2 based on real-time lightCycler PCR: fast and highly reliable carrier testing and prediction of severity of spinal muscular atrophy. Am J Hum Genet. 2002, 70: 358-368.

[3] De Sanctis R, Coratti G, Pasternak A, et al. Developmental milestones in type I spinal muscular atrophy. Neuromuscul Disord. 2016, 26: 754-759

[4] Finkel RS, McDermott MP, Kaufmann P, et al. Observational study of spinal muscular atrophy type I and implications for clinical trials. Neurology 2014; 83: 810-817.

[5] Kolb SJ, Kissel JT. Spinal muscular atrophy. Neurol Clin. 2015; 33: 831-846

[6] State Secretariat for Health, Ministry of Human Capacities Health care guidelines for the diagnostics and therapy of spinal muscular atrophy. [Egészségügyi szakmai irányelv a spinális muscularis atrophiáról, klinikumáról és kezeléséről.] Emberi Erőforrások Minisztériuma, Egészségügyért Felelős Államtitkárság, 2018. Available from: https://www.hbcs.hu/uploads/jogszabaly/2731/fajlok/EMMI_szakmai_iranyelve_spinalis_muscularis\%20.pdf [Hungarian]

[7] Verhaart IE, Robertson A, Leary R, et al. A multi-source approach to determine SMA incidence and research ready population. J Neurol. 2017; 264: 1465-1473.

[8] Kolb SJ, Coffey CS, Yankey JW, et al. Baseline results of the NeuroNEXTspinal muscular atrophy infant biomarker study. Ann Clin Transl Neurol. 2016; 3: 132-145.
[9] Finkel RS, Mercuri E, Darras BT, et al. Nusinersen versus sham control in infantile-onset spinal muscular atrophy. $\mathrm{N}$ Engl J Med. 2017; 377: 1723-1732.

[10] Szirmai I. (ed.) Neurogenic muscle diseases. Spinal muscular atrophy. [A neurogén izombetegségek. Spinalis muscularis atrophiák.] Medicina Könyvkiadó, Budapest, 2011. [Hungarian]

[11] Mercuri E, Finkel RS, Muntoni F, et al. Diagnosis and management of spinal muscular atrophy. Part 1. Recommendations for diagnosis, rehabilitation, orthopedic and nutritional care. Neuromusc Disord. 2018; 28: 103-115.

[12] Wurster CD, Ludolph AC. Nusinersen for spinal muscular atrophy. Ther Adv Neurol Disord. 2018, 11: 1756285618754459.

[13] Mendell JR, Al-Zaidy S, Shell R, et al. Single-dose gene-replacement therapy for spinal muscular atrophy. N Engl J Med. 2017; 377: 1713-1722.

[14] Kawasaki T, Kawai T. Toll-like receptor signaling pathways. Front Immunol. 2014; 5: 461 .

[15] Corti M, Elder M, Falk D, et al. B-cell depletion is protective against anti-AAV capsid immune response: a human subject case study. Mol Ther Methods Clin Dev. 2014; 1: 14033.

[16] Chicoine LG, Montgomery CL, Bremer WG, et al. Plasmapheresis eliminates the negative impact of AAV antibodies on microdystrophin gene expression following vascular delivery. Mol Ther. $2014 ; 22$ : 338-347.

[17] Goldshmit Y, Kanner S, Zacs M, et al. Rapamycin increases neuronal survival, reduces inflammation and astrocyte proliferation after spinal cord injury. Mol Cell Neurosci. 2015; 68: 82-91.

[18] Murlidharan G, Samulski RJ, Asokan A. Biology of adeno-associated viral vectors in the central nervous system. Front $\mathrm{Mol} \mathrm{Neu-}$ rosci. 2014; 7: 76 .

[19] Petrosyan HA, Alessi V, Singh V, et al. Transduction efficiency of neurons and glial cells by AAV-1, $-5,-9,-$ rhl 0 and -hull serotypes in rat spinal cord following contusion injury. Gene Ther. 2014; 21: 991-1000

[20] Cearley CN, Wolfe JH. Transduction characteristics of adenoassociated virus vectors expressing cap serotypes 7, 8, 9, and Rh10 in the mouse brain. Mol Ther. 2006; 13: 528-537.

[21] Glanzman AM, Mazzone E, Main M, et al. The Children's Hospital of Philadelphia Infant Test of Neuromuscular Disorders (CHOP INTEND): test development and reliability. Neuromuscul Disord. 2010; 20: 155-161.

[22] Hammersmith Functional Motor Scale Expanded for SMA (HFMSE). March 29, 2019. Available from: http://columbiasma.org/docs/HFMSE_2019_Manual.pdf

[23] Overview of the ZOLGENSMA clinical studies. Available from: https://www.zolgensma.com/clinical-studies

[24] Al-Zaidy SA, Mendell JR. From clinical trials to clinical practice: practical considerations for gene replacement therapy in SMA type 1. Pediatr Neurol. 2019; 100: 3-11.

[25] Hoy SM. Onasemnogene abeparvovec: first global approval. Drugs 2019; 79: 1255-1262.

[26] Stevens D, Claborn MK, Gildon BL, et al. Onasemnogene abeparvovec-xioi: gene therapy for spinal muscular atrophy. Ann Pharmacother. 2020; 54: 1001-1009.

[27] Hodinka L, Vereckei E, Gasparik AL. Sarcopenia and quality of life: the validated Hungarian translation of the Sarcopenia Quality of Life (SarQoL) questionnaire. [Sarcopenia és életminőség: a Sarcopenia Quality of Life (SarQoL) kérdőív hiteles magyar fordítása]. Orv Hetil. 2018; 159: 1483-1486. [Hungarian]

[28] Valkó L, Baglyas S, Tamáska E, et al. Use of noninvasive ventilation in critically ill patients. [Nem invazív lélegeztetés alkalmazása kritikus állapotú betegekben]. Orv Hetil. 2018; 159: 18311837. [Hungarian]

(Mikos Borbála dr., Budapest, Bethesda u. 3., 1146 e-mail: Mikos.Borbala@bethesda.hu)

A cikk a Creative Commons Attribution 4.0 International License (https://creativecommons.org/licenses/nc/4.0/) feltételei szerint publikált Open Access közlemény 